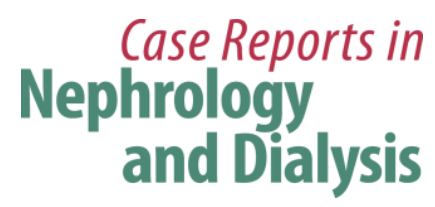

Case Rep Nephrol Dial 2018;8:76-81

DOI: $10.1159 / 000488642$

Published online: April 26, 2018

(C) 2018 The Author(s)

Published by S. Karger AG, Basel

www.karger.com/cnd

This article is licensed under the Creative Commons Attribution-NonCommercial 4.0 International License (CC BY-NC) (http://www.karger.com/Services/OpenAccessLicense). Usage and distribution for commercial purposes requires written permission.

\title{
Accidental Insertion of a Peritoneal Dialysis Catheter in the Urinary Bladder
}

\author{
Shivraj Riar ${ }^{\mathrm{a}}$ Mohammed Abdulhadi $^{\mathrm{b}}$ Christine Day ${ }^{\mathrm{c}}$ Bhanu Prasad $^{\mathrm{b}}$ \\ aCollege of Medicine, University of Saskatchewan, Regina, SK, Canada; ${ }^{b}$ Section of \\ Nephrology, Department of Medicine, Regina General Hospital, Regina, SK, Canada; \\ 'Peritoneal Dialysis, Regina General Hospital, Regina, SK, Canada
}

\section{Keywords}

Peritoneal dialysis · Tenckhoff catheter - Urinary bladder · End-stage renal disease

\section{Abstract}

Percutaneous insertion of a peritoneal dialysis (PD) catheter has inherent risks of complications, more so if done "blind" (without fluoroscopy and ultrasound guidance). Despite the perceived disadvantages, there are very few reported cases of mechanical complications after PD catheter insertion. We present an 81-year-old man who underwent percutaneous insertion of dual-cuffed coiled Tenckhoff PD catheter under local anesthesia by a trained nephrologist. The procedure was uneventful, and the patient was discharged 45 min later in a stable state. A day later, he noticed a decline in the urine output. A week later at a scheduled clinic visit, upon unclamping the PD catheter, there was a sudden gush of amber colored fluid. A diagnostic CT scan confirmed the presence of PD catheter entering the abdominal cavity inferior to the umbilicus and the distal end coiled in the urinary bladder. This case illustrates the need for prophylactic Foley catheterization in individuals at high risk for a distended bladder either as a consequence of a mechanical obstruction from an enlarged prostate or due to a neurogenic bladder while undergoing "blind" percutaneous placement.

(C) 2018 The Author(s)

Published by S. Karger AG, Basel 


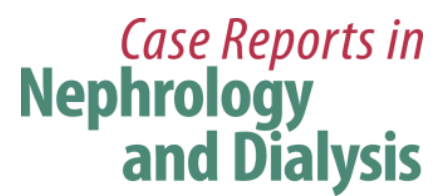

Case Rep Nephrol Dial 2018;8:76-81

DOI: $10.1159 / 000488642$

2018 The Author(s). Published by S. Karger AG, Base www.karger.com/cnd

Riar et al.: Accidental Insertion of a Peritoneal Dialysis Catheter in the Urinary Bladder

\section{Introduction}

Peritoneal dialysis (PD) catheters were typically placed by general surgeons in the operating room by open surgical dissection or by laparoscopic placement. The significant economic advantage of PD over in-center hemodialysis added to the excessive wait times for surgical placement of catheters has led to nephrologists being trained to insert catheters. Open surgical dissection and laparoscopic placement have the advantage of precise catheter placement with minimal possibility of viscus perforation. Disadvantages include requirement of general anesthesia, longer recovery times, and greater institutional costs.

Bedside insertion of PD catheters by nephrologists using the percutaneous retrograde Seldinger technique carries a greater risk of mechanical complications like perforation of the bowel/bladder, improper placement, and/or vessel wall injury. Use of fluoroscopy guidance decreases the risk of complications but its availability is dependent on institutional resources.

\section{Case Report}

An 81-year-old man underwent insertion of a double-cuffed Tenckhoff dialysis catheter under local anesthesia without fluoroscopy or ultrasound guidance. Two years before, he was diagnosed as having acute kidney injury as a consequence of ANCA-positive vasculitis. Despite being adequately treated with age-appropriate doses of immunosuppression, he progressed to end-stage renal disease (ESRD) and was referred to a trained nephrologist for bedside placement of PD catheter upon becoming symptomatic of uremia. He was counseled for the procedure with a training video and underwent standardized preprocedure bowel care (Table 1).

Fifteen minutes prior to commencing the procedure, the patient was sent to void to ensure that there was no residual urine in the bladder. A horizontal $2-\mathrm{cm}$ incision was made just below the umbilicus, followed by blunt dissection of subcutaneous tissue up to the fascia of the rectus muscle. The peritoneal cavity was then cannulated with a Veress needle, and an attempt was made to instill $2.0 \mathrm{~L}$ of heparinized $1.5 \%$ DIANEAL PD solution. He complained of mild lower abdominal discomfort after $1.8 \mathrm{~L}$ of solution was instilled, and the infusion was discontinued. Abdominal discomfort resolved once infusion stopped. We then proceeded with insertion of a guide wire through the Veress needle into the abdominal cavity. A peelaway sheath and introducer were inserted over the guide wire. The introducer was removed along with the guide wire, leaving the peel-away sheath in situ. The PD catheter was advanced through the peel-away sheath and directed caudally toward the left iliac fossa, thus splitting the peel-away sheath. An 8- to $10-\mathrm{cm}$ tunnel was created to the selected exit site with the placement of the distal cuff subcutaneously, $2 \mathrm{~cm}$ from the exit site.

Immediately after the procedure, amber-colored fluid filled the drainage bag when the drain clamp was released. A complete drain in the indwelling dialysate was performed and the total volume returned was approximately the same amount as the instilled volume. In retrospect, the drainage color was unusual, but we felt that the amber color was likely a result of residual ascites often seen in patients with ESRD. He was hemodynamically stable 


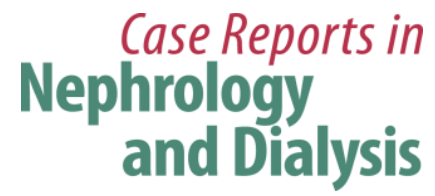

Case Rep Nephrol Dial 2018;8:76-81

during the procedure, and 30 min later, was mobilizing independently and was documented to be pain free.

One week after PD catheter insertion, the patient was scheduled for a standard $1.0 \mathrm{~L}$ flush of dialysate. He instantaneously drained $1.1 \mathrm{~L}$ of dark amber-colored fluid on unclamping the PD catheter. Again, the initial drain volume was attributed to residual ascites. He denied any pain or discomfort after the procedure and was otherwise well. A week later, he came back for another scheduled visit, and upon unclamping the catheter, he further drained $1.1 \mathrm{~L}$ of dark amber-colored fluid. At this time, upon further questioning, the patient noted that he was experiencing a decline in his urine output, which began a day after insertion of the PD catheter. Clinical examination was unremarkable; there was no abdominal tenderness, rigidity, or guarding, and bowel sounds were audible and normal. He remained hemodynamically stable throughout his postprocedure follow-up period. There was no clinical evidence of ascites. Declining urine output, along with instantaneous drainage of ambercolored fluid upon unclamping the PD catheter prompted us to investigate him further. His serum urea and creatinine were 18.4 and $592 \mu \mathrm{mol} / \mathrm{L}$, respectively. Twenty-four-hour urine collection revealed the following: volume $1,300 \mathrm{~mL}$; protein $0.4 \mathrm{~g} /$ day (normal range: 0.00 $0.15 \mathrm{~g} /$ day); urine creatinine 4,100 $\mu \mathrm{mol} / \mathrm{L}$ (normal range: 7,100-18,000 $\mu \mathrm{mol} /$ day); and creatinine clearance $5 \mathrm{~mL} / \mathrm{min}$. Peritoneal fluid (drained from the PD catheter was amber colored and analysis revealed the following: creatinine $2,189 \mu \mathrm{mol} / \mathrm{L}$, glucose $0.8 \mathrm{mmol} / \mathrm{L}$ (7.0-10 mmol/L); Gram stain was negative, and the differential did not show any additional white cells. As the biochemical results were suspicious of PD catheter in the urinary bladder, he underwent a CT of the abdomen and pelvis, which revealed a PD catheter entering the abdomen inferior to the umbilicus (Fig. 1) and coiled within its cavity (Fig. 2). There was no evidence of bowel injury, intraperitoneal free gas, or free fluid.

Upon discovery of the bladder perforation, the patient's PD catheter was removed. A Foley catheter was placed to decompress the bladder to assist with the healing of the site of accidental insertion. The patient eventually had a successful PD catheter introduced under laparoscopic guidance by the general surgeon. The Foley catheter was removed 3 months later under the supervision of the urologist. He was diagnosed as having urinary retention related to an enlarged prostate. He is now undergoing scheduled ambulatory PD, coping well on therapy and voiding well independently.

\section{Discussion and Conclusions}

In publicly funded health care models, there is a significant economic advantage of patients undergoing PD compared to in-center hemodialysis. A recent cost analysis done by a Canadian center showed that the cost of PD was CAD 38,658 compared to CAD 64,214 for incenter hemodialysis [1]. This cost advantage in addition to delays in surgical access (long wait times for initial visits to see surgeons, operating room spots) has led to programs to train nephrologists to insert bedside PD catheters using an aseptic technique in ambulatory care units. Institutional resources dictate availability of fluoroscopy for the procedures.

The notable disadvantage of percutaneous PD catheter insertions without imaging guidance is the inability to visualize the peritoneal cavity but has the advantage of rapid, bedside insertion under local anesthesia [2]. Despite its potential, the risk of perforation of the viscus 

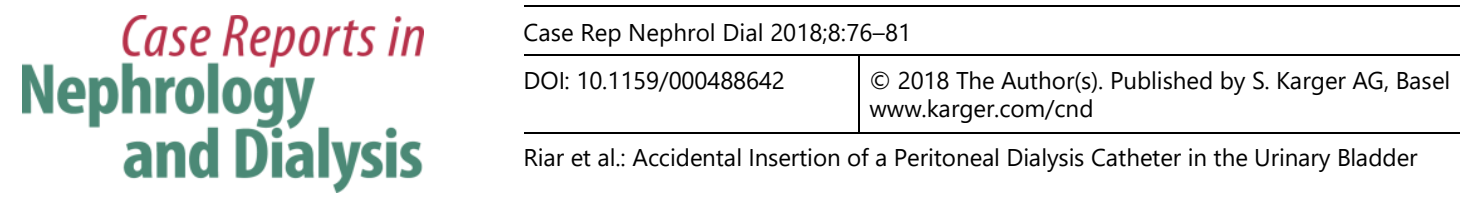

is low, even in nonsurgical hands [3, 4]. Insertion of a PD catheter into the bladder is a rare complication, as suggested by only 15 reported cases over 3 decades [3, 4]. This complication can be prevented by inserting a urinary catheter before the procedure in selected cases, such as those with symptoms of lower urinary tract obstruction, or a neurogenic bladder [3]. The risk can be mitigated if performed under fluoroscopy guidance.

\section{Statement of Ethics}

Written informed consent was obtained from the patient for publication of this case report.

\section{Disclosure Statement}

The authors declare that they have no competing interests.

\section{Author Contributions}

S.R. and B.P. wrote the initial draft. B.P., C.D., M.A. edited and revised the drafts. All authors agree with the content in the final draft.

\section{References}

1 Beaudry A, Ferguson TW, Komenda P. Dialysis in Canada: a contemporary cost minimization analysis. Clin J Am Soc Nephrol. Under review.

2 Nasir SA, Bhat MA, Wani MM, Tufail S, Wani IA, Mantoo S. Accidental placement of the continuous ambulatory peritoneal dialysis catheter into the urinary bladder. Saudi J Kidney Dis Transpl. 2013 Mar; 24(2):373-5.

3 Moreiras M, Cuiña L, Rguez Goyanes G, Sobrado JA, Gil P. Inadvertent placement of a Tenckhoff catheter into the urinary bladder. Nephrol Dial Transplant. 1997 Apr;12(4):818-20.

4 Ekart R, Horvat M, Hojs R, Pecovnik-Balon B. An accident with Tenckhoff catheter placement: urinary bladder perforation. Nephrol Dial Transplant. 2006 Jun;21(6):1738-9. 


\section{Case Reports in Nephrology and Dialysis}

Case Rep Nephrol Dial 2018;8:76-81

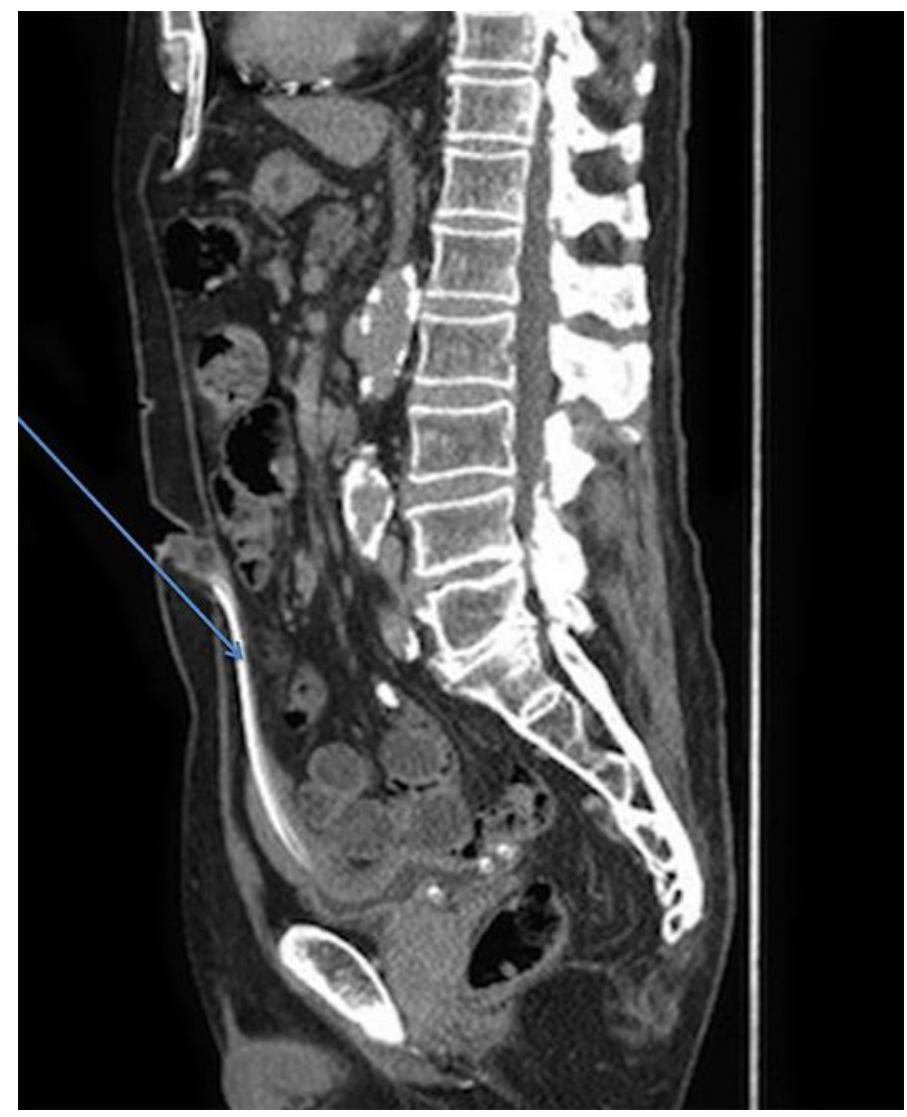

Fig. 1. A sagittal CT image showing insertion of the PD catheter under the umbilicus and entering into the bladder. 


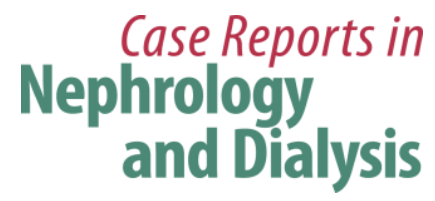

\begin{tabular}{l|l} 
Case Rep Nephrol Dial 2018;8:76-81 \\
\hline DOI: 10.1159/000488642 & $\begin{array}{l}\text { (c) 2018 The Author(s). Published by S. Karger AG, Basel } \\
\text { www.karger.com/cnd }\end{array}$
\end{tabular}

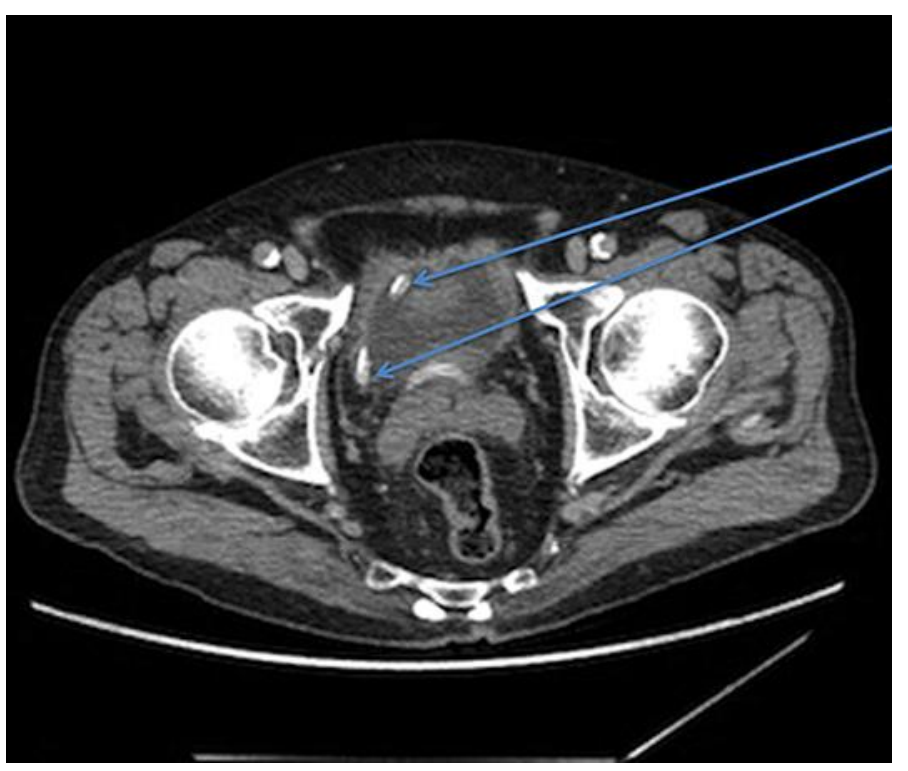

Fig. 2. CT section showing PD catheter in the bladder.

Table 1. Standard preoperative bowel care prior to bedside insertion of peritoneal dialysis catheter

\begin{tabular}{ll}
\hline Time before insertion & Medication/intervention \\
\hline 7 days prior to insertion & Stop all possible constipating drugs (calcium and iron) \\
\hline 3 days prior to insertion & Lactulose $30 \mathrm{~mL}$ p.o. b.i.d. \\
\hline 2 days prior to insertion & $\begin{array}{l}\text { Lactulose } 30 \mathrm{~mL} \text { p.o. b.i.d. } \\
\text { Peg-Lyte or GoLytely 2,000 mL o.d. }\end{array}$ \\
\hline 1 day prior to insertion & Peg-Lyte or GoLytely 2,000 mL o.d. \\
\hline Day of insertion & $\begin{array}{l}\text { Abdominal X-ray prior to procedure to confirm procedure is safe to } \\
\text { proceed }\end{array}$ \\
\hline
\end{tabular}

